\title{
Learning from Brazilian Indigenous Peoples: Towards a Decolonial Education
}

\author{
Special issue: South-South Dialogues: Global Approaches to Decolonial Pedagogies
}

\author{
Reinaldo Matias Fleuri ${ }^{1}$ and Lilian Jurkevicz Fleuri ${ }^{2}$ \\ ${ }^{1}$ Programa de Pós-Graduação Interdisciplinar em Ciências Humanas, Universidade Federal de Santa Catarina, Brazil \\ ${ }^{2}$ School of Language and Comparative Cultural Studies, The University of Queensland, St Lucia 4072, Australia
}

\begin{abstract}
This study argues that western societies have to learn from the cosmological vision of first peoples. In the Brazilian context, despite the genocide of these peoples, there still remains a rich variety of cultures, keeping their traditions and lifestyles based on the concept of buen vivir, in Spanish, or Tekó Porã as the Guarani people say. From a decolonial intercultural approach, we can learn a sustainable way of life from indigenous peoples, and create relevant policies and educational frameworks. Principles of buen vivir such as cooperation and reciprocity are incorporated by Paulo Freire in his dialogic pedagogy. Freire has incorporated these principles due to his engagement with social and communitarian movements. For this reason, his pedagogical proposal is not limited to school contexts only; it is rather linked to community and social praxis. This political transformation of educational praxis involves changes in the modern-colonial matrix of power and knowledge. Deconstructing racism and the myth of universality is necessary for recognizing epistemic rationalities developed by indigenous communities, in order for us to establish with them critical dialogue and mutually enriching interaction. In this sense, the newly introduced term neologism 'conversity' indicates intercultural dialogue resulting from the recognition of indigenous peoples and social movements as producers of legitimate knowledge and autonomous organisation.
\end{abstract}

Keywords: Brazilian Indigenous peoples, interculturalism, decolonial education, social movements, Paulo Freire, conversity

Throughout over 500 years of colonization, the Brazilian indigenous peoples have had their lives and ancestral territories taken, and their culture shrouded and ignored. Despite the drastic reduction of the first people (indigenous population), representing today $0.4 \%$ of Brazil's inhabitants, they resist, perpetuating their cultures, languages, and knowledge through generations. First peoples of Brazil conceive of and practice human coexistence with the environment, through the concept of buen vivir, as the Guarani people, in their rescued nation, Pindorama and culture, Tekó Porã, along with the peoples of Abya Yala. Today, the children of 'Mother Earth' fight against the project of modernisation and the colonial process, both of which have been establishing the capitalist mode of production while negatively affecting natural resources, individuals and cultures of all indigenous peoples.

In this article, we argue that the modern colonial logic can to some extent be reversed and attenuated when we listen to these peoples. Although Europeans have colonized by enforcing their own power and knowledge, such colonizers' descendants can learn from first peoples' lives, through their concept of buen vivir. This can be put into practice establishing a critical intercultural dialogue with indigenous peoples, which reinvents noncolonial modes of life and deconstructs relations of power.

Decolonizing depends on recognizing the relativity of Euro-universalism; it means recognizing 'that "dialogue" can only take place when the "monologue" of one civilization (western) is no longer enforced' (Mignolo, 2005, p. xix). Some decolonial and noncolonial perspectives have

ADDRESS FOR CORRESPONDENCE: Reinaldo Matias Fleuri, Programa de Pós-Graduação Interdisciplinar em Ciências Humanas, Universidade Federal de Santa Catarina, Campus Universitário Trindade, 88.040-900 Florianópolis, Brazil. Email: fleuri@pq.cnpq.br. 
been given voice by first peoples, through their expressed values and lifestyle, which are also being studied by different authors (Porto-Gonçalves, 2015). From a critical interculturalist viewpoint, in dialogue with indigenous peoples we can all open our minds to a sustainable way of life, widen our political basis for action and connect our educational praxis with intercultural cooperation and environmental sustainability.

We recognize the principles of buen vivir in the popular education theory of Paulo Freire, a Brazilian sociointeractionist pedagogue who founded his discussion on commitment to social movements. His dialogic educational methodology is supported by the concepts of cooperation and reciprocity between teachers and students, as between any other sociocultural agents. Through dialogue, Freire argues that communities face their social contradictions and are then able to organise themselves politically and overcome social and political struggles imposed by the colonial system. We will name this dialogic praxis, rooted in Paulo Freire's theory and in indigenous cultures, conversity, or a way to cultivate processes of knowledge and power through permanent conversation with popular and first peoples' social movements.

This article is organised into four sections plus some final considerations. This introduction is followed by a contextualizing of the situation of the indigenous peoples in Brazil with an overview of indigenous data in the 2010 Brazilian Census. Next, comes an explanation of interculturalism and decolonial perspectives, based on the perspective of Walsh (2012), who sets out critical interculturalism as a necessary decolonial project, and of Gauthier (2011), who believes that oppressed people are interested in revealing, analysing and criticising foundations of oppression. Section Education: Communitarian dialogue and social praxis proposes an intercultural dialogue between the mainstream and indigenous people, involving unpacking the sustainable way of life of the first peoples of Brazil and their concept of buen vivir, policies for buen vivir and the educational social praxis proposed by Paulo Freire which implies changes in the modern colonial matrix of power and knowledge. By doing so, this paper demonstrates that the worldview of indigenous peoples can teach us a sustainable philosophy of living, and generate relevant policies and educational frameworks.

\section{Indigenous Peoples and the Colonial Process of Brazil}

When the Portuguese began colonizing the area, Brazil was invented through the process of settlement, colonial domination and exploitation of its land and peoples. The colonial discourse - founded on racist conceptions, ranking the world population by the criterion of 'race', or physical features - reinforced and still reinforces human domination over indigenous peoples. Unable to understand the languages and cultures of indigenous peoples, European colonizers represented them, through negative contrast to European cultures, as 'uncivilized', 'uneducated', 'illiterate' people, assigning them to a subordinate position. The ethnocentric worldview of European cultures, which defined themselves as unique and universally superior, induced the conquerors to see people of different cultures as primitives: 'culture also served the colonial purpose of naming and describing those alien and inferior cultures that would be under European civilization' (Mignolo, 2005, p. xvii).

The word 'Indian' started to be used by Europeans of the 16th century to simplistically refer to the indigenous people of the 'new world'. Such a generic term was first used by Christopher Columbus, in 1492, to define the people the crew was supposed to meet. In the context of maritime expansion and European trade, Columbus' intended destination was what is now known as India, reached by sailing in the opposite direction to the norm, with the aim of eventually circumnavigating the globe to return to Europe. When they landed on the unknown continent, the explorers believed they had reached the 'West Indies', and the name 'Indians', was maintained to identify, classify and standardise the first peoples of the 'new world', ignoring their numerous cultural identities across the continent. The name 'Indian', then, defines the indigenous peoples of the Americas, in opposition to those of European descent, enhancing an ethnic identity and boundary (Luciano, 2006). However, to avoid pejorative connotations, we prefer to use the terms 'first peoples', 'original peoples' or 'indigenous' to name the autochthonous population that, at the beginning of colonization, had already been settled in the territories of the Americas.

As colonization started in the Americas, the ignorance and deprecation of indigenous cultures lead to a massive destruction of these peoples. When the first Portuguese reached Brazil's coast in 1500, Portugal's population was approximately 1.2 million people, representing $1.8 \%$ of the European population of 60 million (Serrão, 1996, p. 63). At this time, there were an estimated 4 million indigenous people living in Brazilian territories. Despite some divergence between demographic studies about indigenous peoples in Latin America (Carneiro da Cunha, 2012), it is known that more than 1000 different nations coexisted in the area of precolonial Brazil. These comprised about 1400 ethnic groups, with different forms of social, political, cultural, territorial and linguistic organisation (Pagliaro, Azevedo, \& Santos, 2005). At that time, the indigenous population was demographically far more numerous than the Portuguese colonizers, and with complex ethnic and cultural diversity. It is astonishing that Portuguese, a minority language in 16th century Europe, has become Brazil's official language, whilst the languages and cultures of original peoples, enormous in their own ethnic variety, were almost extinguished, becoming socioculturally invisible in less than 500 years. 
Despite that, there still survives a rich ethnic variety of indigenous communities in Brazil. The Brazilian Census held in 2010, registered 896,900 indigenous residents. This corresponds to $0.4 \%$ of its current 203.2 million inhabitants (IBGE, 2012). Its diversity is considerable with 305 ethnic groups and 274 languages spoken in Brazil. Portuguese, though, is still dominant among the indigenous population: only $37.4 \%$ of them speak an indigenous language and $76.9 \%$ speak Portuguese. Original peoples are present in five regions of Brazil. The northern region, which includes the Amazon area, holds the largest number, 342,800 , and the southern region, the lowest, 78,800 . Nationally, 502,700 live in rural areas and 315,200 in urban. The 2010 Brazil Census also shows 505 territories demarcated as indigenous domains. These represent 106.7 million hectares (12.5\% of Brazil's territory), home to 517,400 indigenous people $(57.7 \%$ of 896,900 indigenous Brazilians).

The three most numerous indigenous peoples of Brazil are the Tikuna, in Amazonia, with 46,045 people; the Guarani Kaiowá, in Mato Grosso do Sul, with 43,401; and the Kaingang, in the states of São Paulo, Paraná, Santa Catarina and Rio Grande do Sul, adding up to a total of 37,470 (IBGE, 2012). With populations of between 9000 and 29,000 are the following peoples: the Macushi, Terena, Tenetehara, Yanomami, Potiguara Pataxó, Sateré-Mawé, Mundurukú, Múra, Xucuru, Baré, Pankararu, Kokama, Wapixana, Kayapó and Xacriabá. This numerically small and diverse population of first peoples in Brazil's territory has resisted the colonial process that started at the beginning of the 16th century by the Portuguese conquerors, multiple waves of immigration commencing in the 19th and the globalization of the international market in the 20th and 21st.

The ancestors of today's indigenous peoples named their continent using different approaches. Pindorama (etymologically 'region of palm trees') is a designation for the mythical place of the Tupi-Guarani people, a land free of evil (Clastres, 1978). This name and its related orally transmitted history were formed at the time of the ancient migrations of the Tupi-Guarani to the eastern coastal region of Brazil. Several Tupi-Guarani groups inhabited the region before the 'Pindorama invasion' by Portuguese colonizers, known to Europeans as the 'discovery of Brazil'. Abya Yala is the name chosen in 1992 by indigenous nations to describe the continent, instead of 'America'. The name 'America' was given by the conquerors who paid tribute to Amerigo Vespucci, believed to have been the first European seafaring explorer to land on the continent. Abya Yala comes from the language of the Kuna, a people of Panama and Colombia before the arrival of Columbus. Abya Yala means 'land in its full maturity' or simply 'land of splendour' and it refers to the entire land mass, from Alaska to Patagonia. Although the different peoples attribute specific names to the regions they occupied, the term Abya Yala has been increasingly adopted by original peoples of both continents, aiming to build a sense of unity and belonging.

\section{Intercultural Challenges}

Intercultural relationships must consider the projects, proposals, meanings, actions, choices, languages and feelings of all involved peoples. Often intercultural relations are deeply conflicting and dramatic. Historically, encounters between different peoples have resulted in wars, genocides and domination. Understanding the logic of mutual destruction may help to develop creative and dialogical relations between different sociocultural groups. Walsh (2012), a researcher at Simon Bolivar University in Ecuador, explores the multiple senses and uses of interculturalism, through three different perspectives: relational, functional and critical interculturalism.

The first, relational interculturalism, refers to the contact and interchange between different cultures as something that has always existed. It considers miscegenation a natural process of syncretism and transculturation. This relational perspective hides or reduces the conflicts and contexts of power and domination, restricting the relationships to an individual level. Social, political, economic and even epistemic structures, which represent cultural differences in terms of superiority or inferiority, are obscured.

Walsh names the second perspective functional interculturalism, which has roots in the acceptance of cultural differences and their establishment into a social structure. This perspective promotes dialogue, companionship, and tolerance, but it does not question the causes of asymmetry and sociocultural inequity. Following the new multicultural logic of global capitalism, this perspective recognizes and manages, in a functional way, sociocultural differences to expand the modern world system. It does not point towards creating more equitable and egalitarian societies, but to controlling ethnic conflicts by the inclusion of historically excluded groups in a functional way to maintain social stability under the economic imperatives of the neo-liberal model of capitalist accumulation.

The third perspective considered by Walsh - critical interculturalism - questions colonial racist structures and their link to capitalism, pointing to the construction of different societies. Critical interculturalism is an appeal from the social groups that have historically suffered oppression, as well as the sectors that struggle alongside them, for social transformation and decolonization, and for the building of a better world. For this approach, the main intercultural issue is not ethnic and cultural diversity, but the differences created as the colonial power pattern permeates virtually all layers of life. It is about understanding and creating interculturalism within the political, social, ethical and epistemic project. In this way, the aim is to intervene over the power matrix of colonialism and transform the mechanisms that maintain 
the subjugation of human beings, knowledge, logics and ways of life, and especially acts of racial and cultural exclusion.

\section{Decolonial Perspective}

Many intellectuals and activists have been developing studies from a decolonialist perspective. According to Carlos Walter Porto-Gonçalves, 'there is a huge theoretical and political legacy that comes from Guaman Poma de Ayala, Simon Roberts, Simon Bolivar, Jose Artigas, José Maria Caycedo, Jose Marti, Emiliano Zapata, Jose Carlos Mariategui, Franz Fanon, Ayme Cesaire, C. R. James, Pablo Gonzalez Casanova, Zavaleta Mercado, Florestan Fernandes, Silvia Rivera Cusicanqui, Rachel Gutierrez, Anibal Quijano, Maristela Svampa, Enrique Leff, Enrique Dussel, Walter Mignolo, Ramon Grosfogel, Catherine Walsh, Arturo Escobar, Rui Mauro Marini, Giarraca Standard, Raul Zibechi, Pablo Mamani and Alberto Acosta, among many others, that we shall consider for deep critical analysis of the modern colonial capitalist world, in its historical and structural heterogeneity.' (Porto-Gonçalves, 2015, p. 246).

Since the 2000s, Catherine Walsh has participated in the collective Modernity/Coloniality/Decoloniality Project (MCD). 'The theoretical program called Modernity/Coloniality/Decoloniality (MCD) aims at decolonizing modern thought by rewriting global history from the perspective of local histories' (de Vries, 2013). This group originated from the Latin-American Group of Subaltern Studies, inspired in 1990 by the South-Asian Group of Subaltern Studies and incorporating themes addressed by the Indian historian Ranajit Guha. Its intention was to move towards a reconstruction of Latin American history. The MCD Group, under the leadership of Walter Mignolo, considers subordination a postmodern critique (which represents a Eurocentric criticism about Eurocentrism) and seeks to develop a decolonial critique within a social science framework (which represents a criticism of Eurocentrism by formerly silenced and subaltern knowledge) (Grosfoguel, 2008, p. 116). From this perspective, critical interculturalism sets out a much needed decolonial plan of logical investigation and policy development. This aims to conceptualize and confront the colonial power matrix that historically links the idea of 'race' as a classification and tool of social control with the global capitalist development (modern, colonial, Eurocentric) initiated as part of America's historical formation.

'Colonialism' is concerned with the political and economic domination of one people over another, anywhere in the world. Beyond the social dimension, 'coloniality' indicates the pattern of relationships that emerges in European colonization on the American continents and is constituted as a modern and permanent power model. Quijano sums this up as 'coloniality is one of the constitutive and specific elements of the global status of capitalist power. It is based on the imposition of a racial and ethnic classification of the population of the world as a cornerstone of the pattern of power and operates in each of the plans, materials and subjective spheres and in the dimensions of everyday social existence and the social scale. It originates and is globalised from America.' (Quijano, 2000, p. 342).

According to Walsh (2012), to build interculturalism in a critical way demands trespassing on and dismantling the current colonial matrix in capitalism and creating other conditions of power, knowledge, being and living, which point to the possibility of living together in a new order and logic that come from complementary and social singularities. Interculturalism must be considered as an intentional, steady, continuous and even insurgent action, interlaced and advanced with the action of decolonizing.

The decolonizing process implies deconstruction, first, of the coloniality of power based on 'race' as the fundamental criterion for the distribution, domination, and exploitation of the world population in the context of global capitalist work. This implies critically reviewing the coloniality of knowledge, the assumption that Europe is the centre of knowledge production that dismisses the possibility of epistemic rationality and knowledge generated by other peoples and cultures. Another challenge is to fight the coloniality of being, or the subordination and dehumanization of colonized peoples, empowering their human value and the cognitions founded in their ancestral roots. Finally, yet importantly, these intercultural educational initiatives aim to overcome the coloniality of nature and life itself, criticising the binary division of nature and society, empowering the relationship with ancient biophysical human and spiritual worlds, promoting the magical, spiritual and social beliefs that support the whole socioecological system and knowledge of original peoples. By enabling this holistic relationship with nature, it is possible to regard these people's ways of being, knowing and organising their lives and thus dismantle the racism perpetrated by colonial modernity.

Although the MCD Group has not developed any discussion about and with Brazil, and there is not a Brazilian researcher currently associated with this group (Ballestrin, 2013, p. 111), many Brazilian researchers have oriented their work around deconstructing the logic of coloniality in their interaction with indigenous peoples.

With this objective, Calderoni and Nascimento (2012) studied the relationship between colonial logic and traditional knowledge in indigenous village schools. They address the challenges posed to indigenous education as negotiation and translation between traditional and western knowledge. They point to the importance of revising colonial thinking and the need for an epistemological redefinition of knowledge legitimated by formal indigenous education. Within the intercultural critical perspective, they advocate the importance of considering the complexities and ambivalences produced in the educational 
process, when bodies of knowledge, which are intrinsically different, meet each other.

Other Latin American authors have sought to go beyond criticism of colonialism and coloniality. Valencia (2015) proposes a noncolonial intercultural perspective: 'it shares with decoloniality the starting point of both the consciousness of the colonial state and its total rejection, but differs from some versions of decolonial thought, whose position and efforts are focused on critical analysis of the colonial epistemic framework, in terms of refutation. As distinct from decolonial, noncolonial is here understood as a self-determined and creative affirmation of critical consciousness and all human dimensions.' (Valencia, 2015, p. 12).

According to the noncolonial perspective, the interactions and conversations between peoples of different cultures who aware of their autonomy and values question the sense of their actions and their speech, as well as the epistemic and ethnic backgrounds of each community. Within such radical intercultural conversation and collaboration, each cultural group may grow up epistemologically and ethically by reciprocal peer and self-criticism.

Living within communities of indigenous people from the Peruvian Amazon, Gasché (2012) realized that the values shared by various such peoples of the Amazon rainforest are not recognized by either the Brazilian or Peruvian societies. Gashé understood that while values are implicit in these communities' daily activities, because of the lack of suitable vocabulary and language structures in Portuguese or Spanish, indigenous peoples cannot express their own values. In addition, as they cannot contrast them with capitalist and urban social values, neither do they recognize their own values. Gashé proposes an educational method to help these communities to identify their singular values and to explain them in the dominant language. By doing so, he believes that these communities would gain autonomy to identify the differences between their own and the dominant sociocultural values, and make choices in relation to these.

From a similar intercultural perspective, Gauthier (2011) believes that oppressed people have a vital interest in revealing, analysing and criticising the hidden foundations of the oppressions to which they are subjected. Furthermore, this author considers that indigenous people have implicit knowledge, unknown to other cultural groups, which could be explained through intercultural dialogue.

However, academics of European descent, such as myself, assume the position of establishing an intercultural dialogue with indigenous peoples (as with other cultures), we must be open to a radical critique of the epistemological assumptions about our culture and the other's: 'each group (academic and popular) shows to the other what the other cannot see, which is the institutionally contextualized character of one's science, even those considered actually universal' (Gauthier, 2011, p. 80). Thus, the 'concept of dialogue expresses the dual need for mutuallysensitive listening and mutual criticism about the illusions and blindness present before the epistemological ruptures' (Gauthier, 2011, p. 49). By doing so, we can ask ourselves with a critical attitude towards constitutive colonial epistemology of Euro-descendant scientific training - 'what do we learn through intercultural dialogue with Abya Yala peoples?'

\section{What are We Learning from First Peoples?}

'We must learn to be indigenous before it is too late!' said the anthropologist Eduardo Viveiros de Castro, at the 'Tristes Trópicos' (Sad Tropics) Colloquium, held on August 2, 2014, at the International Literary Festival of Paraty - FLIP (Ferraz, 2014). According to Castro, now is the moment when Planet Earth is being threatened by issues provoked by climate change and global warming and transformed into an 'unbreathable place'. We must learn from indigenous people 'how to live in a country without destroying it, how to live in a world without demolishing it (...). The original peoples have much to contribute to a more democratic and diverse country (...). The meeting with the indigenous world leads us to the future, not the past' (Ferraz, 2014). Through the worldview or 'cosmovision' of first peoples, the buen vivir, we can learn a sustainable way of life, and create relevant policies and educational frameworks.

\section{A Sustainable Way of Life}

Benites explained that a very important dimension in the autochthonous way of life is the holistic ecological worldview: the world is a living being and the human being is a living part of this world. Eliel Benites is a former KaiowáGuaraní student, and is currently a professor in the Federal University of Grande Dourados - UFGD, Brazil. Therefore, preserving nature is a key condition for the survival of every community. This worldview is the opposite of the dominant perspective in the capitalist mode of production, which seeks to exploit the land and turn it into property and its products, into merchandise.

Today, many autochthonous communities live on reserves surrounded by farms. This prevents the practice of hunting and fishing, the basis of their economic, political and cultural organisation. The indigenous peoples are more vulnerable than ever, under the onslaught of landowners and large economic projects, as well as political activities that curtail the demarcation and autonomous processes of indigenous territories. 'Initiatives focused on the international market meet the expectation of powerful economic corporations, especially multinationals, in the areas of mining, oil and gas, soybean monoculture, sugarcane, livestock farming, the cellulose industry, agro-fuel production, timber and other natural resource exploitation. They also benefit the powerful construction indus- 
try, which donates generous amounts of money to support the campaigns of political parties, confident that they will receive it all back, double.' (Heck, Silva, Feitosa, 2012, p. 25).

However, indigenous peoples have established a harmonious relationship with the land and nature over millennia. By doing so, they have strongly questioned the predatory logic of so-called 'development' in 'modernisation', which understands economic growth based on overexploiting natural resources and maintaining unsustainable patterns of consumption. In opposition to international programs, which want to convert the indigenous lands into 'transit' territories for goods, mined holes, and oil-polluted rivers, the Coordination of Andean Indigenous Organisations (Coordinadora Andina de Organisaciones Indígenas - CAOI) defends the buen vivir as a legitimate alternative, as living in balance with nature and spirituality: 'we are children of the 'Pachamama', not its owners or rulers, vendors or destroyers. Our life depends on it. For this reason, for thousands of years, we have built our own way of life, or Sumaq Kawsay/Sumaq Qa-maña.' (Heck, Silva, Feitosa, 2012, p. 25).

Often loosely translated to 'good living' or 'living well', the concept of buen vivir (Sumak Kawsai in Quechua; Suma Qa-maña in Aymara; Tekó Porã in Guarani) means 'good way of being and living and learning in coexistence with nature'. This wisdom, present in most Amerindian cultures, shows us that the relationship between all living beings on the planet has to be maintained in balance. It focuses on living sustainably as a member of a community that includes both human beings and nature. Buen vivir seeks to change the relationship between nature and humans to a more bio-pluralistic view, eliminating the separation between nature and society. Buen vivir is a 'community paradigm of life culture oriented to living well'. It is sustained in a way of living reflected in daily practices of respect, harmony, and balance with existence. It understands that in life everything is interconnected, interdependent, and interrelated.' (Mamani, 2010).

Most Brazilian indigenous cultures, like other AbyaYala cultures, understand the Earth as a mother which protects and nurtures life through a practice of giving and reciprocity. Just as nature cares for and makes human life possible, human beings, by reciprocity, are invited to care for and protect nature. In Guarani cosmology, according to the testimony of Eliel Benites, it is inconceivable that the land could be considered as an object of ownership and exchange, because the earth has its own life and 'it cannot move to anywhere and cannot be transported by humans (... ) Nature sustains and controls the possibilities of life for humans. So, humans must care and respect nature, in order to ensure their chances of existence' (Benites, 2002).

The respect for and preservation of nature implies the political articulation of life in the community, through various forms of collective and harmonious living. Bartomeu Melià, a Jesuit linguist and anthropologist, explains the
Guarani people's conception of buen vivir: 'Tekó Porã is a good way to be in a good state of life, good living and living well. It is a state of bliss, joy, and satisfaction; a happy and enjoyable, pleasant and peaceful state. There is a good life when there is harmony with nature and with members of the community, when there is sufficient food, health, and tranquility, when the 'divine abundance' allows reciprocal economy, jopoit, i.e., 'open hands' of one person to the other.'(Melià, 2013, p. 194).

Such a view of life and nature contrasts with the view of Euro-descendant cultures: nature is conceived as an object to be dominated, appropriated and commoditized. This way of seeing the world justifies a process of predatory exploitation of the environment, as well as their own workforce, to achieve the accumulation of private capital. Such a system is now in deep crisis, along with the worldview and the ideologies that justify it. From the perspective of buen vivir, which corresponds to the historical desire for the emancipation and unity of the Abya-Yala people, autonomous life at the small scale, and sustainable and balanced management of environment are necessary to ensure a dignified existence for all and to ensure the Earth's survival. Buen vivir is also expressed in the political articulation of life, through practices such as local assemblies, common spaces of socialization, parks and urban gardens, cooperatives of production and consumption, and various forms of harmonious collective practices of living.

By integrating biophysical, human and spiritual dimensions, indigenous peoples' ancient cosmovision allows them to overcome the modern conception of life that divides nature and society and justifies the exploitation and rapacious domination of nature by humans. Thus, indigenous cultures offer a worldview that may have prospects for overcoming the impasse in which Eurocentric cultures and the capitalist system are today, with regard to global ecological sustainability.

\section{Policies of Buen Vivir}

Brazil's original peoples continue waging significant resistance struggles also through active participation in the political life of the country. They seek to enter positively in the state's political, judicial, legislative, cultural and social system, trying to live and maintain their identities as indigenous people. For this, they seek to strengthen their identities and their territories by self-managing, as well as developing practices of intercultural relations. For example, they assume the environmental management of national parks, develop their own educational policies and intercultural activities in the city and the countryside and collaborate with other social movements.

Indigenous Brazilian peoples have also sought to participate in the state's political system, but have a marginal participation in political parties of the nation. The Brazilian Constitution of 1988 recognized the right of indigenous people to have their representatives apply for public office as a mayor, member of the congress and member 
of the assembly. Among the best known indigenous figures are Mario Juruna (1943-2002), the first indigenous congress member in Brazil (1982-1986), and João Neves Silva, who was Brazil's first indigenous mayor, elected in 2002 in the city of Oiapoque in Amapá. The survey of the Indigenous Missionary Council (CIMI) in 2010 indicates about 10 elected indigenous mayors in Brazilian cities, 4 vice mayors, and at least 60 assemblymen. The latest achievement in indigenous politics was the creation, in 2006, of the National Commission of Indigenous Policy (CNPI - Comissão Nacional de Políticas Indígenas, in Portuguese), which established a discussion forum with the indigenous peoples themselves, regarding the preparation of indigenous federal public policy. This is the only space in Brazil today in which first peoples can exercise some social control over public policies designed for them. However, the CNPI is consultative rather than mandatory. This means that everything that is discussed and voted on by this commission is only advisory and the government is not required to implement such proposals.

Original Brazilian peoples' attempts to participate in the Brazilian political scenario have revealed a paradox. Benites (2002) clarified that 'upon taking up the colonizers' way of life, many First Nations have lost their identity and autonomy. Now' - said Eliel - 'we, Guarani communities, seek to rethink these challenges based on our needs and our ancestral way of seeing the world' (Benites, 2002). The political organisation of Brazilian indigenous peoples - Tekó Porã, for the Guarani - buen vivir is based on dialogue and cooperation in the community. It is incompatible with the type of political organisation of the state, based on party politics. That contradiction becomes very clear in the electoral processes in which political candidates not only seek and use the votes of the indigenous, but also induce them to take a form of political organisation based on parties, contrary to their way of understanding the participatory process of community organisation.

This contradiction brings into question the status of the currently hegemonic form of political organisation of the nation state, assumed by independence processes in the American continent. Studies carried out in different national contexts in Latin America - in Peru (Gasché, 2010; Marín, 2010), Argentina (Díaz and Villarreal, 2010), Chile (Guzmán, 2012) and Guatemala (Esquit, 2010), among others - show a critical intercultural view expounded by original peoples, who were historically colonized and subordinated in the process of the constitution of these nation states. On one hand, this historical process configured the independence of the American territories in relation to their colonial European powers. However, on the other hand, it maintained the subordination and political and cultural invisibility of indigenous peoples. States were formed based on cultural prejudice that recognizes only one national identity, incorporating the interests of the colonial elites to maintain their political and economic control within a capitalist system.
The fights of indigenous peoples, therefore, do not fit political struggles of the nation states, which follow an exclusionary and oppressive political model. By defending their cultures and their forms of social organisation and politics, indigenous peoples struggle for 'life, dignity and territory. Several of these movements indicate that "life" cannot be imagined outside of nature, as conceived by the Eurocentric scientific tradition. (... "Dignity" is a claim for respect of their condition as another being, equally dignified, which is constantly denied by the coloniality of modernity $(\ldots)$; it is finally, the right to be different $(. .$.$) Because culture is not something abstract,$ these movements point out that the material conditions are necessary for creating their means of life. "Territory" is the category that combines nature and culture through relations of power over the material conditions of life. (...) By these means, they signalize that multiple territorialities dwell in the same territorial state (...). This is a debate about territorial autonomy, plurinationality, and nature's rights, as inscribed in the new constitutions of Ecuador and Bolivia. No more national state, a plurination one instead.' (Porto-Gonçalves, 2015).

The struggles for constructing plurinational forms of state, as proposed by the Plurinational Bolivian State (Tapia, 2007), are significant for overcoming the coloniality of power. This coloniality of power is sustained on the assumption of a superiority of one ethnic group over another, or of the universality of a nation. It refutes the cultural difference and political autonomy of peoples who can democratically constitute a plurinational state.

\section{Education: Communitarian Dialogue and Social Praxis}

The Brazilian indigenous people, despite their very rich complexity and diversity, share a worldview based on buen vivir with most Amerindian societies. They also share quite a different educational perspective from the European colonial one. Their education emphasises personal autonomy and community participation. Eliel Benites assumed that western colonial peoples improve education 'outside in'. His people (Kaiowá Guarani), on the contrary, seek today to develop education 'inside out'. As Eliel said: 'it's like a covered fountain that, when clear, spouts water in abundance. This gushing water is a reflection, a reflection that has the ability to rethink their long-term project: what will become of our people in a hundred years? Reflection thus constitutes a key element in the constitution of the way of understanding the relationship of the Guarani with the world.' (Benites, 2002).

Recent educational policies formally recognize the diversity and ethnic and cultural plurality of Brazilian society. Regarding the indigenous, the 1988 Federal Constitution and the 1996 Law of Guidelines and Bases of National Education of Brazil take important steps in formulating general principles aimed at a differentiated edu- 
cation, both bilingual and intercultural. However, Marcon (2010, pp. 97-118) questions to what extent and in what way the legislation on indigenous intercultural education was constructed in dialogue with different indigenous groups.

First people communities face the challenge of how they could reproduce and consolidate their original cultures in the context of school education, which is oriented to pass on and reproduce the national culture, represented by the monocultural state.

In this sense, school seems to exist ambivalently: while it reproduces the national monoculture, school is also traversed by multiple local cultures. While school endorses disciplinary subjection and exclusion strategies, daily life in school holds various interactions and resistance movements. Such a paradox puts school organisation into crisis. School is bound to deconstruct subject areas and monocultural backgrounds and foster complex relationships between individuals and their respective sociocultural contexts.

Under this perspective, the educational proposal of Paulo Freire, author of 'Pedagogy of the Oppressed' acquires particular relevance (Freire, 2006). Throughout the 1970s, the pedagogy of Paulo Freire found a great acceptance in all continents among educators working in community organisations and social movements, because he both criticised traditional education and understood education as an important political tool for ethnic and social minorities. The liberating education proposed by Freire questions the profoundly unequal current social structure and helps educators to reflect on their own historical experience, mobilizing them to collectively perform social transformations with a democratic perspective. The literacy method created by Paulo Freire, for example, is based on a set of dialogic strategies of education that favour the development of critical awareness, interpretation and deep understanding of social problems through collective dialogue, combined with social and political praxis.

Although Paulo Freire has formulated his pedagogical concept based on critical theories referenced to Eurodescendant cultures, through his engagement with popular social movements he absorbed epistemological backgrounds of indigenous cultures of Latin America. Thus, it is possible to identify principles of buen vivir, Tekó Porã, in his dialogical methodology. Cooperation and reciprocity between teachers and students are what characterizes his methodology, promoting an atmosphere of mutual acceptance, respect, understanding and interactive communication.

Paulo Freire systematized an educational proposal based on 'cultural circles' - discussion groups in which teachers and students develop dialogues on issues regarding their life conditions and draw collective organising strategies to overcome the challenges they face. In this context 'debated topics' (temas geradores) are formulated as complex experiences encoding political meaning, trigger- ing discussions and critical reflection. These experiences arise from the life stories of participants of the dialogic process of education. In a literacy program, for example, these topics generate words, made up of syllables that, when separated, can be used to form other words that belong to the context of a student's life. Therefore, reading and writing represent and become contextually significant. Through this method, students develop a critical understanding about the world they live in, creating tools and strategies to improve cooperative actions and to combat oppressive structures. Such a pedagogical perspective is inspired by intercultural research projects, in which different participants, interacting equally and mutually, engage in an effort to critically understand their reality and their struggles for social transformation. Construct sustain.

Freire's pedagogical proposals criticise educational perspectives centred on the content and the teacher; the type of education that understands the student as a mere recipient of information proposed exclusively by the teacher. Freire formulates a dialogical and dialectical epistemological perspective which understands that people educate themselves through interactions, mediated by the world. It allows them to promote a reciprocal interaction and to comprehend and transform sociocultural environments. In this sense, Paulo Freire has a decolonial educational concept that reinforces the noncolonial perspective.

Inspired by Freire's conception, many decolonial social movements recognize themselves in the critical interaction with various sociocultural agents. These agents act as protagonists of culture production and knowledge when they enhance the dialectics, intercultural and political dimensions of their social and educational praxis. Social groups require recognition as culture creators, as a precursor to what Stoer (2008) has designated as 'difference's rebellion', This quest leads to a need to develop complex mechanisms and processes of mediation and dialogue between the different sociocultural agents, which we would call conversity. In coining this new term, we want to point to the urgency, in regard to social movements, for educational projects that enhance dialogue between the different coexisting sociocultural agents, in a complex epistemological perspective.

Conversity is built through dialogues and cooperation between different peoples who take on the fundamental challenges of their context and commit to actions and strategies for building a democracy which creates radical and cooperative solutions. Therefore, it means to form and strengthen dialogue and coexistence, through multiple and complex means and different strategies, processes, languages and narratives, promoting and sustaining relationships of mutual learning between various participants and between their respective cultures (conversity). Thus, one seeks to understand and solve, critically and creatively, the major social, economic, political, cultural and environmental problems we face in today's world. Sustainability is one of the main challenges we now 
face. By dialogical praxis engaging with original peoples and communitarian social movements we could improve buen vivir through social, political and educational strategies, and move towards a decolonial society.

\section{Final Considerations}

Coloniality, the project of modernity (Mignolo, 2005), brought the indigenous peoples of the Americas to the brink of extinction. Such genocides in Latin America are part of a paradoxical dimension of the process of globalization in the modern colonial world. By inserting and expanding the capitalist mode of production through the exploitation of natural resources, the ecosystem has been systematically destroyed together with indigenous cultures and innumerable individuals who were its original guardians. In this tragic context, learning from first peoples' ways of life may lead to a future where people rescue the concept and practices of buen vivir, making sustainable living in harmony with Mother Earth a reality. Modernity drew paradise, Coloniality drew the buen vivir. 'Dialogue today is a 'utopia' and it should be reconceived as 'utopistic': a double movement composed of a critical take on the past in order to imagine and construct future possible worlds' (Mignolo, 2005, p. xix). To establish a critical intercultural dialogue with indigenous peoples, it is necessary to deconstruct colonial principles and to promote the construction of noncolonial modes of being, living, power, and knowledge. Decolonializing implies continuous and rebellious dialogue and intercultural cooperation, reinventing noncolonial modes of life.

Going beyond the binary Euro-descendant conception of nature and society, the concept of buen vivir, cultivated and worshipped by the people of Abya Yala, fosters the life systems of first peoples. Revaluing this holistic relationship, woven through dialogic community practices integrated with the natural world, is necessary to deconstruct the ethnically prejudiced matrix of colonial relations of power. This matrix is responsible for promoting the distribution, domination, and exploitation of the world's population in the capitalist context of work. Deconstructing this matrix of power implies reconfiguring the legal and political relations of the state, going beyond the imposition of monocultural nationalism. It also implies facilitating intercultural coexistence, avoiding the denial and subalternization of social-cultural differences. Facilitating intercultural coexistence should rather enhance critical and creative social relationships between social agents and their cultural contexts. Several Latin American countries, driven by the struggles of indigenous peoples, have incorporated principles of buen vivir and the rights of Mother Earth into their national policies.

This political transformation involves changes in the modern colonial matrix of knowledge. By recognizing the uniqueness and relativity of Euro-descendent cultures, it is possible to deconstruct the myth of its universality. In this way, epistemic rationalities developed by indigenous communities and social movements can be recognized, in order for them to establish critical dialogue and mutual and enriching interaction. In this sense, conversity results from the recognition of indigenous peoples as producers of legitimate knowledge and autonomous organisation.

Even intellectual Euro-descendants engaged with social movements, developers of critical theories and educational proposals have much to learn from interaction with indigenous people in Brazil via a decolonial or noncolonial perspective. In this regard, the educational proposal of Paulo Freire may be reconsidered. Education, understood by Freire as a dialogic process for questioning and transforming unfair sociocultural relations, is presented as a political tool in favour of social and ethnic minorities.

Nevertheless, sociopolitical movements conducted in partnership with first peoples push the political activities beyond the limits of the nation state and anthropocentrism. This creates perspectives for political organisation capable of supporting bio-cultural diversity and preserving the rights of nature. Indigenous social movements aim to radically change the global colonial system, not only to take control of the nation state, but, as the Zapatistas propose: 'changing the world without taking the state' (Holloway, 2002, p. 32). The Abya Yala peoples actually defend the priority for the rights of the Earth and new systems of plurinational states.

Paulo Freire's ideas are based on western theories but identify the epistemological principles of buen vivir, Tekó Porã, in his dialogical methodology, such as cooperation and reciprocity in the teacher-student relationship. It seems likely Freire has incorporated these principles from his participation in social movements. For this reason, his pedagogical proposal is not confined to the school context, but rather linked to community and social praxis. In Freire's pedagogy, the educational strategy of the circle of culture stimulates dialogues about the social contradictions that the community faces on a daily basis and promotes a political organisation that leads them to overcome them. In this way, we learn with the indigenous cultures that social and political struggles do not only require changes in the modern colonial world system. Such efforts, rather, seek to rebuild social relations in intercultural and transcultural perspective (Gauthier, 2011; Padilha, 2004). From this standpoint, individual education through the interpersonal dialogue mediated by questioning the world (Freire, 2006) will improve sociocultural and epistemic transformation of their contexts.

\section{Acknowledgments}

This paper is a result of the research project "Intercultural and ecological challenges for scientific and technological education" sponsored by $\mathrm{CNPq}$ (National Council for Scientific and Technological Development, Brazil) and 
CAPES (Coordination for the Improvement of Higher Education Personnel, Brazil). We, Dr Reinaldo Matias Fleuri and Dr Lilian Jurkevicz Fleuri acknowledge that this manuscript is an original work and that has not been submitted to nor published anywhere else.

\section{References}

Ballestrin, L. (2013). América Latina e o giro decolonial. Revista Brasileira de Ciência Política, 2, 89-117 (Impresso).

Benites, E. (2002). Seminário Fronteiras etno-culturais e fronteiras da exclusão: Desafio da interculturalidade e da equidade. Tema: A Etnicidade no contexto de uma sociedade intercultural. Campo Grande, MS, 16 a 19 de setembro de 2002 (unpublished report).

Calderoni, V.A.M. de O., Nascimento, A.C. (2012). Saberes tradicionais indígenas, saberes ocidentais, suas intersecções na educação escolar indígena. Revista Visão Global, Joaçaba, 15(1-2), 303-318.

Carneiro da Cunha, M. (2012). Índios no Brasil: História, direitos e cidadania. São Paulo: Claro Enigma.

Clastres, H. (1978). Terra sem mal: O profetismo TupiGuarani. São Paulo: Brasiliense.

de Vries, P. (2013). Comunidad y desarrollo en los Andes Peruanos: Una crítica etnográfica al programa de modernidad/colonialidad. Sociologias, 15(33), 248-281.

Díaz, R., Villarreal, J. (2010). Teoría y práctica intercultural: políticas públicas y estrategias interculturales originarias para una articulación con identidade. Revista Espaço Pedagógico, Passo Fundo, 17(2), 189-210.

Esquit, E. (2010). Nociones Kaqchikel sobre la opresión y la lucha política en Guatemala, siglo XX. Revista Espaço Pedagógico, Passo Fundo, 17(2), 252-266.

Ferraz, M.G. (2014). 'Temos que aprender a ser índios antes que seja tarde', diz antropólogo. Página B - Brasil (on line). Retrieved September, 18, 2017 from http://www. paginab.com.br/brasil/temos-que-aprender-ser-indiosantes-que-seja-tarde-diz-antropologo\#.WcAyc9N96-o

Freire, P. (2006). Pedagogy of the oppressed (30th Anniversary edn.). New York: Continuum.

Gasché, J. (2010). La ignorancia reina, la estupidez domina y la conchudez aprovecha. Engorde neo-liberal y dieta bosquesina. Revista Espaço Pedagógico, Passo Fundo, $17(2), 279-305$.

Gasché, J. (2012). ¿Qué valores sociales bosquesinos enseñar en las escuelas de la Amazonia Rural? Revista Pedagógica, 14(28), 49-86.

Gauthier, J. (2011). Demorei tanto para chegar ... ou: Nos vales da epistemologia transcultural da vacuidade. Tellus, 11(20), 39-67.

Grosfoguel, R. (2008). Para descolonizar os estudos de economia política e os estudos pós-coloniais: Transmodernidade, pensamento de fronteira e colonialidade global. Revista Crítica de Ciências Sociais, 80, 115-147.

Guzmán, B.R. (2012). Interculturalidade em questão: análise crítica a partir do caso da Educação Intercultural Bilíngue no Chile. Revista Pedagógica. Chapecó, 1(28), 87-118.
Heck, D.E., Silva, R.S., Feitosa, S.F. (organisadores) (2012). Povos indígenas: Aqueles que devem viver - Manifesto contra os decretos de exterminio. Brasília: CIMI - Conselho Indigenista Missionário.

Holloway, J. (2002). Change the world without taking power. London: Pluto Press.

Instituto Brasileiro de Geografia e Estatística (IBGE). (2012). Censo Demográfico 2010. Características gerais dos indígenas. Resultados do universo. Rio de Janeiro: IBGE.

Luciano, G.S. (2006). O Índio Brasileiro: O que você precisa saber sobre os povos indigenas no Brasil de hoje. Brasília: MEC/ SECAD; LACED/ Museu Nacional.

Mamani, F.H. (2010). Buen Vivir/Vivir Bien: Filosofía, políticas, estrategias y experiencias regionales andinas. Lima: Coordinadora Andina de Organisaciones Indígenas.

Marcon, T. (2010). Educação indígena diferenciada, bilíngue e intercultural no contexto das políticas de ações afirmativas. Revista Visão Global. Joaçaba, 13(1), 97-118.

Marín, J.P. (2010). Estado-Nación y sociedad multicultural. Perspectiva actual. Revista Visão Global. Joaçaba, 13(2), 287-322.

Melià, B. (2013). Palavras ditas e escutadas - entrevista. Mana, 19(1), 181-199.

Mignolo, W. (2005). The idea of Latin America. Malden (USA), Oxford (UK), Victoria (Australia): Blackwell Publishing.

Quijano, A. (2000). Colonialidad del poder y clasificación social. Journal of World-Systems Research, 11(2), 342386.

Padilha, P.R. (2004). Currículo Inter-transcultural: Novos itinerários para a educação. São Paulo: Cortez/IPF.

Pagliaro, H., Azevedo, M.M., Santos, R.V. (organisadores). (2005). Demografia dos povos indígenas no Brasil. Rio de Janeiro: Editora FIOCRUZ.

Porto-Gonçalves, C.W. (2015). Pela vida, pela dignidade e pelo território: Um novo léxico teórico político desde as lutas sociais na América Latina/Abya Yala/Quilombola. Polis (Santiago), 14(41), 237-251.

Serrão, J.V. (1996). População e rede urbana nos séculos XVIXVIII. In O. César (Ed.), História dos municípios e do poder local (dos finais da Idade Média à União Europeia) (pp. 6377). Lisboa: Círculo de Leitores.

Stoer, S. (2008). Novas formas de cidadania, a construção europeia e a reconfiguração da universidade. Educação, Sociedade \& Culturas, 26, 219-238.

Tapia, L. (2007). Una reflexión sobre la idea de Estado plurinacional. OSAL (Buenos Aires: CLACSO) (08) 22, 47-63.

Valencia, M.A.C. (2015). Ojo de Jíbaro. Conocimiento desde el tercer espacio visual. Prácticas estéticas contemporáneas en el Eje Cafetero colombiano. Popayán: Editorial Universidad de Cauca.

Walsh, C. (2012). Interculturalidad y (de)colonialidad: Perspectivas críticas y políticas. Revista Visão Global, 15(1-2), 61-74. 


\section{About the Authors}

Reinaldo Matias Fleuri is a Senior Professor at the Universidade Federal Santa Catarina - UFSC, and Instituto Federal Catarinense - IFC (Brazil). He is also an Honorary Professor at The University of Queensland and Griffith University. He is responsible for the coordination of the network study of "Intercultural Education and Social Movements" (UFSC/CNPq).

Lilian Jurkevicz Fleuri holds a $\mathrm{PhD}$ degree in critical translation studies from the Universidade Federal de Santa Catarina (UFSC/Brazil). She currently works for the School of Language and Comparative Cultural Studies, The University of Queensland, where she lectures and coordinated courses of Latin American Studies and Languages. 